Check for updates

Cite this: RSC Adv., 2017, 7, 34110

\title{
Enantioselectivity of D-amino acid oxidase in the presence of ionic liquids $\uparrow$
}

\author{
Qingju Liu, ${ }^{a}$ Chuanfang Zhao, ${ }^{a}$ Jincheng Huang, (DD a Li Chen, ${ }^{a}$ Kunhao Yang, ${ }^{a}$ \\ Lingling Gong, ${ }^{a}$ Yuguo Du, ${ }^{a}$ Chuyi Yu, (D) ${ }^{c}$ Li Wu, (D) *a Xiangjun Li ${ }^{\star a}$ and Yujian He ${ }^{\star a a b}$
}

In this paper, enantioselectivities of D-amino acid oxidase (DAAO) in ten ionic liquids were investigated in detail. Among the ionic liquids studied, 3-methylimidazolium formate ([MIM][COO]) was able to trigger enzyme activation with L-Ala as substrate. The enzyme activity of DAAO reached a maximum of $4.26 \mathrm{U}$ $\mathrm{mg}^{-1} \mathrm{~min}^{-1}$ in the presence of 40\% [MIM][COO], while no activity toward L-Ala was observed when DAAO was incubated with other ILs. Moreover, DAAO activities towards other L-amino acids such as LPro and L-Arg were also improved in [MIM][COO], which indicated that the enzymatic enantioselectivity of amino acids was lowered. This was further confirmed by capillary electrophoresis, circular dichrosim and fluorescence analysis. Molecular optimization supported that the protein-ionic liquid interactions modulated the structure of the enzyme, especially in [MIM][COO], leading to relaxation in the enantioselectivity of DAAO. This observation and exploration might open a new window for modulation enantioselectivity resolution in ionic liquids.

Received 26th April 2017

Accepted 30th June 2017

DOI: $10.1039 / \mathrm{c} 7 \mathrm{ra04687a}$

rsc.li/rsc-advances between ionic constituents as well as the alkyl chain length of ILs and enzymatic activity and stability have been analysed in detail. $^{3,7-9}$ The enzymatic behaviours have been improved in ILs (higher enantioselectivity and better recoverability and recyclability) due to high conversion rates. ${ }^{10-13}$ Interestingly, enzymatic reactions in the presence of ILs have provided useful information on the enzymes flexibility and stability, enzyme inhibition, behaviour of enzyme. ${ }^{\mathbf{1 4 , 1 5}}$

In general, by optimization of the type and concentration of ILs, utilization of ILs as co-solvents greatly enhances the enzymatic activity and stability. However, little attention has been devoted to the control of substrate enantioselectivity. Only recently had the stereoselectivity and enantioselectivity of several enzymes in the presence of ILs began to be studied and investigated by several research groups. ${ }^{\mathbf{1 0 - 1 2}}$

Enantiocomplementary enzymes favor opposite enantiomers because either the substrate or the active-site machinery is oriented differently. ${ }^{16}$ In an oxidation example, the active site of D-amino acid oxidase (DAAO) is a mirror image of that of $\mathrm{L}^{-}$ amino acid oxidase (LAAO). Both enzymes catalyze amino acid oxidation, but with opposite enantiomer preference. ${ }^{17}$ However, there are some exceptions to this rule. For example, the LAAO from Bacillus carotarum 2Pfa accepts $10 \mathrm{~L}$-amino acids and 7 Damino acids as substrates (ie, D-Leu, D-Lys and D-Ser). ${ }^{18}$ Also, catalytic oxidation of $\mathrm{L}$-Pro by DAAO at high concentrations has been confirmed. ${ }^{19}$ Moreover, it is acknowledged that the alteration of enzyme enantioselectivity can be achieved by reaction temperature, ${ }^{20}$ biomimetic encapsulation, ${ }^{21}$ directed evolution, ${ }^{22}$ site-directed mutagenesis. ${ }^{23,24}$ In addition, our recent work has shown that the DAAO can catalytically oxidize many L-
${ }^{a}$ School of Chemistry and Chemical Engineering, University of Chinese Academy of Sciences, Beijing, 101408, PR China.E-mail: wuli@ucas.ac.cn; lixiangj@ucas.ac.cn; heyujian@ucas.ac.cn; Fax: +8610 69672529; Tel: +861069672529

${ }^{b}$ State Key Laboratory of Natural and Biomimetic Drugs, Peking University, Beijing, 100191, PR China

${ }^{c}$ Laboratory of Molecular Recognition and Selective Synthesis, Institute of Chemistry Chinese Academy of Sciences, Beijing, 100191, PR China

$\dagger$ Electronic supplementary information (ESI) available. See DOI: 10.1039/c7ra04687a 
amino acids by modulating $\mathrm{pH}$ of aqueous solution. ${ }^{25}$ Especially, there is only 15.99-fold ( $\mathrm{pH} 8.0$ ) and 14.18-fold ( $\mathrm{pH} 9.8$ ) drop for the enantioselectivity $\left(k_{\text {cat,D-AA }} / k_{\text {cat,L-AA }}\right)$ of Pro and Ala, respectively. In contrast, it's reported that the initial rate of enzymatic deamination for D-amino acids is found to exceed that for L-amino acids by 3000 to 4000 -fold under physiological condition. ${ }^{19}$

In the case of DAAO, Lutz-Wahl et al. ${ }^{26}$ have compared the activity and stability of free and immobilized DAAO from Trigonopsis variabilis in different water-soluble and water-insoluble ionic liquids as well as inorganic solvents. They found that the most promising ILs were $[\mathrm{BMIM}]\left[\mathrm{BF}_{4}\right]$ and $[\mathrm{MMIM}]\left[\mathrm{MMPO}_{4}\right]$. However, the comparison of the enantioselectivity of DAAO was not reported in ILs yet. Altering enantioselectivity of DAAO has been regarded as one of the most remarkable topics in enzymatic reactions, since the stereochemical outcome of a given enzyme-substrate reaction is predetermined in specific target environment. Taking these findings into consideration, a comprehensive study of enzymic enantioselectivity in aqueous solution containing different ILs is necessary, which will provide valuable information to understand the behaviour of enzyme in varied ionic liquids.

In the present work, the enantioselectivities of DAAO in presence of ten ILs were investigated in detail. In particular, we observed the enzymatic activity towards L-Ala in presence of [MIM $][\mathrm{COO}]$ was sharply enhanced. Under optimization conditions of $\mathrm{pH}$ value and temperature in [MIM][COO], the kinetic parameters were determined. Additionally, capillary electrophoresis, circular dichroism and fluorescence analysis were undertaken to support the results. The present review intends to show the modulation of enantioselectivity of DAAO by ILs, and provide mechanistic insights into how different factors contribute to the relaxation of enzymatic enantioselectivity by effect of specific ion in various ILs.

\section{Experimental}

\section{Regents and instruments}

All L-amino acids, sodium 3,9-fluorenylmethyloxycarbonyl (FMOC) and 5-dichloro-2-hydroxybenzenesulfonate (DHBS), imidazole, 3-methylimidazole, 4-aminoantipyrine (4-AAP), were purchased from J\&K Scientific. D-Amino acid oxidase from porcine kidney (pkDAAO, $\geq 8.2$ units per $\mathrm{mg}$ solid) and peroxidase (POD) were obtained from Sigma-Aldrich. ILs were kindly supplied by Process Research Institute, Chinese Academy of Sciences.

\section{DAAO activity in presence of ILs with L-Ala as substrate}

Enzymatic activity of DAAO in presence of ILs was determined by measuring the formation of $\mathrm{H}_{2} \mathrm{O}_{2}$ from L-Ala. ${ }^{27}$ The reaction was performed for $5 \mathrm{~min}$ at $25{ }^{\circ} \mathrm{C}$. Reaction mixtures were carried out in tubes containing borate saline buffer $(50 \mathrm{mM}, \mathrm{pH}$ $=8.5)$, $300 \mathrm{U} \mathrm{L}^{-1}$ POD, $0.275 \mathrm{nM}$ 4-AAP, $5.5 \mathrm{mM}$ DHBS, $0.1 \mathrm{mM}$ FAD and $25 \mathrm{mM}$ L-Ala, various amounts of ILs (0-50\%, v/v), and enzyme at a concentration of $228 \mathrm{U} \mathrm{L}^{-1}$. Negative control experiments without ILs were performed. After addition of 500 $\mu \mathrm{L}$ trichloroacetic acid $(10 \%, \mathrm{w} / \mathrm{v})$, the mixture was centrifuged at $10000 \times g$ for $10 \mathrm{~min}$. After that absorbance change was monitored at $512 \mathrm{~nm}$ using Ultraviolet spectrophotometer (Shimadzu UV-2550). One unit of activity was defined as the amount of $\mathrm{H}_{2} \mathrm{O}_{2}$ produced by $1 \mathrm{mg}$ enzyme per minute under the experimental conditions. All measurements were carried out in 3 repetitions.

\section{Influence of temperature and $\mathrm{pH}$}

The influence of $\mathrm{pH}$ on DAAO activity with $\mathrm{L}$-Ala as substrate was determined by incubating the reaction mixture at $\mathrm{pH}$ values ranging from 5.0 to 12.0 , in the following mix buffer system: $50 \mathrm{mM}$ sodium acetate ( $\mathrm{pH} 4.0-5.5) ; 50 \mathrm{mM}$ sodium phosphate (pH 6.0-8.0); $50 \mathrm{mM}$ borate saline buffer (pH 8.0-9.0); $50 \mathrm{mM}$ borate-NaOH buffer ( $\mathrm{pH}$ 9.5-12.0). To check influence of the $\mathrm{pH}$, DAAO was pre-incubated with predetermined $\mathrm{pH}$ mix buffer solution containing $40 \%(\mathrm{v} / \mathrm{v})[\mathrm{MIM}][\mathrm{COO}]$ for $5 \mathrm{~min}$ at $25{ }^{\circ} \mathrm{C}$, and activity was measured under standard assay condition as described above. The optimum temperature for DAAO activity with L-Ala as substrate was determined by conducting the assay at various temperatures from 20 to $80^{\circ} \mathrm{C}$. The thermostability of the enzyme was measured after pre-incubation of the enzyme in borate saline buffer (50 mM, pH 9.0) containing $40 \%(\mathrm{v} / \mathrm{v})$ of [MIM] [COO] at various temperature for $5 \mathrm{~min}$.

\section{Circular dichroism (CD) spectroscopy}

CD spectroscopic studies were performed using a Jasco-815 spectrophotometer (Jasco, Japan) equipped with a Peltier system for controlling the temperature. The sample was preequilibrated at $25{ }^{\circ} \mathrm{C}$ for $15 \mathrm{~min}$ and the scan speed was fixed for adaptive sampling (error $F$ 0.01) with a response time of $1 \mathrm{~s}$ and $1 \mathrm{~nm}$ bandwidth. The secondary and tertiary structures of DAAO were monitored by using $1.0 \mathrm{~cm}$ path length cuvette. The concentrations of DAAO were $0.4 \mathrm{mg} \mathrm{mL}^{-1}$ in $50 \mathrm{mM}$ borate saline buffer ( $\mathrm{pH}$ 9.0) containing $40 \%$ (v/v) IL. Each sample spectrum was obtained by appropriate blank media without DAAO from the experimental enzyme spectrum.

\section{Fluorescence spectroscopy}

Fluorescence measurements for DAAO were monitored using Jasco FP-750 instrument (Cremello, Italy) at $0.1 \mathrm{mg} \mathrm{L}^{-1}$ protein concentration in $50 \mathrm{mM}$ borate saline buffer containing of various ILs $(40 \%, \mathrm{v} / \mathrm{v})$ (final $\mathrm{pH} 9.0)$. The experiments were performed at $25{ }^{\circ} \mathrm{C}$ by using a $1 \mathrm{~cm}$ sealed cell. Emission fluorescence spectra of Trp were recorded between 300 and $400 \mathrm{~nm}$, with excitation at $280 \mathrm{~nm}$; flavin emission were recorded from 475 to $600 \mathrm{~nm}$, with excitation at $450 \mathrm{~nm}$. A blank medium without enzyme was subtracted to eliminate influence of the fluorescence of the ILs and buffer components on the enzyme fluorescence spectrum. Both the change in fluorescence intensity and the shift in fluorescence maximum wavelength were recorded to monitor the unfolding transition; each spectrum being an average of six spectra. 


\section{Computational details}

The X-ray structure of D-amino acid oxidase download from Protein Data Base (http://www.rcsb.org, PDB code: 1C0P). The ligand FAD was extracted from 1C0P and used as reference, while the [MIM] derived from FAD. Atomic charges of ligands and proteins were calculated with the Gasteiger-Hückel protocol. Surflex-Dock program was used to search possible binding conformations of ligands. Default parameters were used in the Docking computation. FAD was docked into the protein, with a TotalScore 25.36, and the RMSD value was 0.646 , which indicated that parameters used here was reasonable. With all the parameters, [MIM] was docked into the binding site of D-amino acid oxidase, with TotalScore of 3.42, which was much lower than that of FAD.

\section{Results and discussion}

\section{Activity of DAAO with L-Ala in presence of ILS}

Imidazolium-based ILs such as $[\mathrm{BMIM}]\left[\mathrm{BF}_{4}\right],[\mathrm{BMIM}]\left[\mathrm{PF}_{6}\right]$ are commonly and popularly used in study. ${ }^{28}$ Previous experiences and recent literature data have shown that imidazolium and pyridinium-based ILs are efficient and promising for enzymatic reaction, ${ }^{26,29}$ thus, ten kinds of imidazolium and pyridiniumbased ILs were chosen for the comparison of the enantioselectivity of DAAO. The ten kinds of ILs used were 1-butyl-3methylimidazolium tetrafluoroborate ([BMIM $\left.]\left[\mathrm{BF}_{4}\right]\right)$, 1-butyl-3methylimidazolium hexafluorophosphate ([BMIM] $\left.] \mathrm{PF}_{6}\right]$ ), 1ethyl-3-methylimidazolium bromide ([EMIM]Br), 1-hexyl-3methylimidazolium bromide ([HMIM]Br), 1-octyl-3methylimidazolium bromide ([OMIM]Br), $N$-butylpyridinium bromide ([BPy]Br), $N$-methylpyridinium formate ([MPy $][\mathrm{COO}])$,

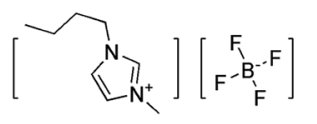

[BMIM][BF 4

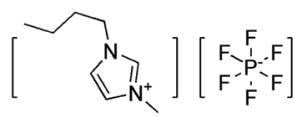

[BMIM][PF6]

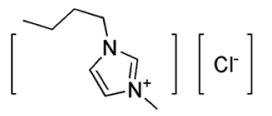

[BMIM][Cl]

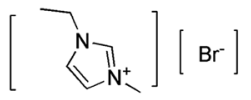

[EMIM][Br]<smiles>CCCCCCn1cc[n+](C)c1</smiles>

[HMIM][Br]

$$
\left[\sim \mathrm{N}^{+}\right]\left[\mathrm{Br}^{-}\right]
$$

[OMIM][Br]

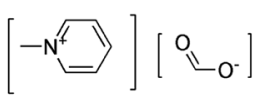

[MPy][COO]

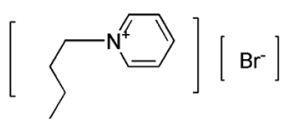

[BPy][Br]

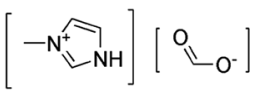

[MIM][COO]

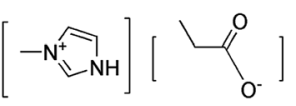

[MIM] $\left[\mathrm{CH}_{3} \mathrm{CH}_{2} \mathrm{COO}\right]$
Fig. 1 Structure of ILs used in this study. 1-butyl-3-methylimidazolium chloride ([BMIM]Cl), 3-methylimidazolium formate ([MIM $][\mathrm{COO}])$ and 3-methylimidazolium propionate ([MIM $\left.]\left[\mathrm{CH}_{3} \mathrm{CH}_{2} \mathrm{COO}\right]\right)$, respectively, and their structures were shown in Fig. 1.

The activities of DAAO with L-Ala as substrate in various ILs were investigated. As summarized in Fig. 2, of all the ILs tested, no detectable activity of DAAO in $[\mathrm{BMIM}]\left[\mathrm{BF}_{4}\right],[\mathrm{BMIM}]\left[\mathrm{PF}_{6}\right]$, [BMIM]Cl, [EMIM]Br, [HMIM]Br, [OMIM]Br, [BPy]Br, [MPy] [COO] and $[\mathrm{MIM}]\left[\mathrm{CH}_{3} \mathrm{CH}_{2} \mathrm{COO}\right]$ was observed. Enantioselectivity of DAAO remained unchanged even at ratios of more than $40 \%$ (v/v) ILs. However, enzymatic activity towards L-Ala showed a sharp increase in [MIM][COO]. With the increase in ratio of [MIM][COO], DAAO activity towards L-Ala was enhanced accordingly. The enzyme activity reached to a maximum $(4.26 \mathrm{U}$ $\mathrm{mg}^{-1} \mathrm{~min}^{-1}$ ) in presence of $40 \%$ [MIM] [COO]. When the ratio of [MIM][COO] was above $40 \%$, the enzyme activity reached a plateau. The results suggested that $[\mathrm{MIM}][\mathrm{COO}]$ disrupted the enantioselectivity of DAAO and improved DAAO activity on $\mathrm{L}^{-}$ Ala.

As we know, one of the most important factors influencing enzyme activity is $\mathrm{pH}$. We employed four common buffer systems in a $\mathrm{pH}$ range of 5.0 to $\mathbf{1 2 . 0}$ for determination. Based on the preliminary study on $\mathrm{pH}$-dependent DAAO activity for the optimization of $\mathrm{pH}$ was performed with $40 \%$ (v/v) [MIM] [COO]. As Fig. 3a shown, enzymatic activity of DAAO with L-Ala as substrate was significantly improved with the increase of $\mathrm{pH}$ value of $[\mathrm{MIM}][\mathrm{COO}]$. It reached a maximum $\left(4.78 \mathrm{U} \mathrm{mg}^{-1}\right.$ $\min ^{-1}$ ) at $\mathrm{pH}$ 9.0. When $\mathrm{pH}$ value of [MIM][COO] was above 9.0, the enzymatic activity of DAAO was sharply decreased. The enzymatic activity became almost negligible at $\mathrm{pH}$ 12.0. In view that temperature could influence the solubility of the reactants and reaction rates, the enzymatic activities altered with the change of temperature. Similarly, the optimal temperature for DAAO activity towards L-Ala was determined in the temperature range from $20^{\circ} \mathrm{C}$ to $80{ }^{\circ} \mathrm{C}$, as shown in Fig. 3b. It's observed that

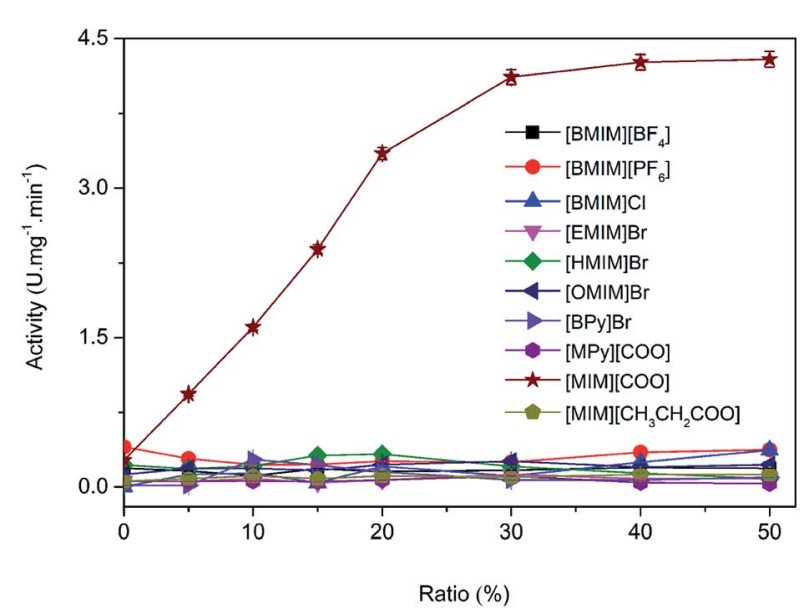

Fig. 2 Enzymatic activity of DAAO in ILs with L-Ala as substrate. Reaction mixtures containing borate saline buffer $(50 \mathrm{mM}, \mathrm{pH}=8.5)$, ILs in a range of concentrations, $228 \mathrm{UL}^{-1}$ DAAO, $300 \mathrm{UL}^{-1} \mathrm{POD}$, $0.275 \mathrm{nM}$ 4-AAP, $5.5 \mathrm{mM}$ DHBS, $0.1 \mathrm{mM}$ FAD and $25 \mathrm{mM}$ L-Ala were incubated for $30 \mathrm{~min}$ at $25^{\circ} \mathrm{C}$. 
a
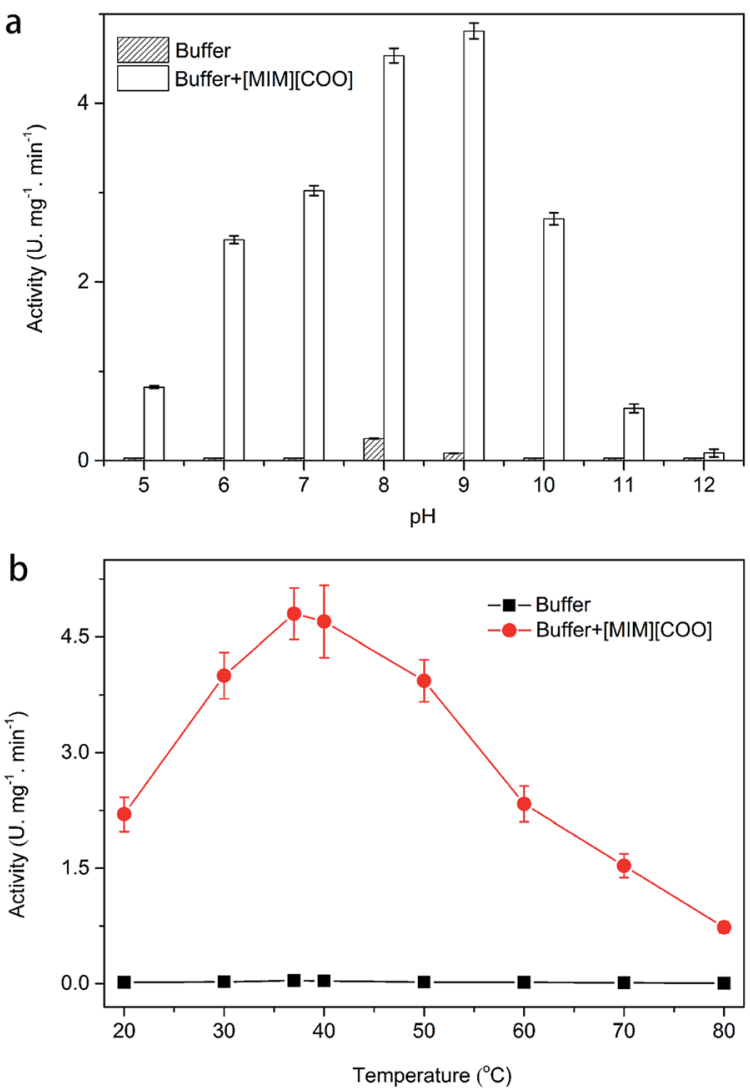

Fig. 3 Optimization of $\mathrm{pH}$ (a) and temperature (b) for DAAO activities towards L-Ala. Reaction mixtures containing 40\% [MIM][COO], $228 \mathrm{U}$ $\mathrm{L}^{-1} \mathrm{DAAO}, 300 \mathrm{U} \mathrm{L}^{-1} \mathrm{POD}, 0.275 \mathrm{nM}$ 4-AAP, $5.5 \mathrm{mM}$ DHBS, $0.1 \mathrm{mM}$ FAD and $25 \mathrm{mM} \mathrm{L}$-Ala were incubated for $30 \mathrm{~min}$.

the activity of DAAO was enhanced with the increase of temperature, and the optimum temperature was about $37^{\circ} \mathrm{C}$. The enzymatic activity was gradually decreased with increase of temperature when the temperature was above $37{ }^{\circ} \mathrm{C}$. Thus, DAAO activities towards various amino acids were assessed under the optimal conditions ( $\mathrm{pH} 9.0$ and $37^{\circ} \mathrm{C}$ ).

Then, the kinetic parameters were determined under the optimum conditions by analysis of Michaelis-Menten plots. DAAO showed a $V_{\max }$ value of $6.1 \pm 0.50 \mathrm{mM} \mathrm{min}^{-1}$ and $K_{\mathrm{m}}$ value of $19.70 \pm 0.30 \mathrm{mM}$ with L-Ala as substrate in the presence of $40 \%(\mathrm{v} / \mathrm{v})$ [MIM] [COO] (Fig. 4). The results indicated that the performance of both binding and catalytic ability of DAAO towards L-Ala was remarkably improved in the presence of $[\mathrm{MIM}][\mathrm{COO}]$.

\section{Activity of DAAO with other L-amino acids as substrate in presence of ILS}

To check whether the observation was occurred for other Lamino acids, the enzymatic activity of DAAO with other L-amino acids as substrate in the presence of [MIM] [COO] was determined. By incubating the enzyme with 5, 20 and $40 \%(\mathrm{v} / \mathrm{v})$ concentrations of [MIM][COO], enzymatic activities were determined in the standard assay conditions. Similar results were obtained and illustrated in Table 1. Noticeably, for L-Trp, L-

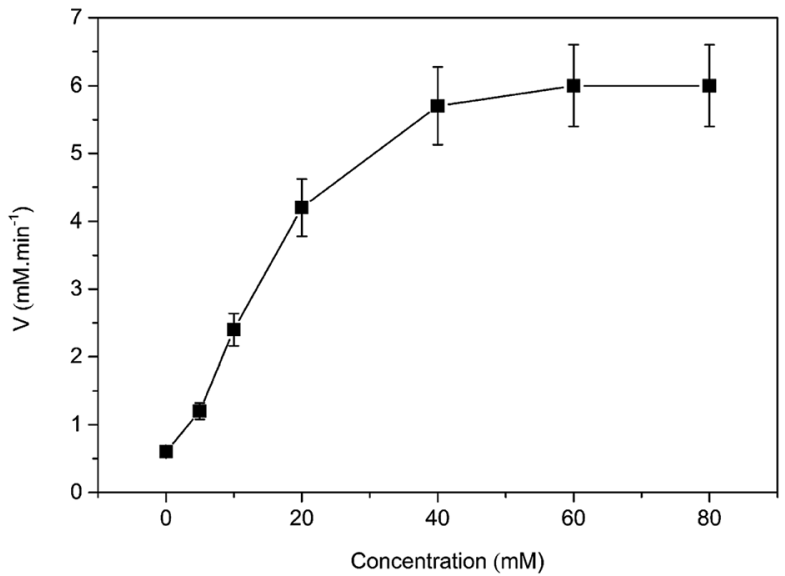

Fig. 4 Michaelis-Menten plots of the DAAO with L-Ala as substrate in presence of $40 \%(\mathrm{v} / \mathrm{v})[\mathrm{MIM}][\mathrm{COO}]$. The experiment was carried out in borate saline buffer $(50 \mathrm{mM}, \mathrm{pH}=9.0)$ at $37^{\circ} \mathrm{C}$.

Asn, L-Cys, the enzyme activity was slightly increased when the [MIM][COO] concentration increased $\left(0.92 \pm 0.08 \mathrm{U} \mathrm{mg}^{-1}\right.$ $\min ^{-1}$ for $\mathrm{L}^{-} \mathrm{Trp}, 0.89 \pm 0.05 \mathrm{U} \mathrm{mg}^{-1} \mathrm{~min}^{-1}$ for $\mathrm{L}$-Asn, $0.39 \pm 0.03$ $\mathrm{U} \mathrm{mg}^{-1} \mathrm{~min}^{-1}$ for L-Cys in $40 \%$ [MIM] [COO]). In contrast, in the case of L-His, L-Thr, L-Gln and L-Arg, activities of DAAO were modestly improved. For example, activity of DAAO towards L-His $\left(\mathrm{U} \mathrm{mg}{ }^{-1} \mathrm{~min}^{-1}\right.$ ) was increased from $0.37 \pm 0.02$ (5\% [MIM] $[\mathrm{COO}])$ to $1.38 \pm 0.11(40 \%$ [MIM] [COO]). More extraordinary, with the increase of $[\mathrm{MIM}][\mathrm{COO}]$ ratio from $5 \%$ to $40 \%$, enzymatic activities were significantly enhanced in presence of $\mathrm{L}^{-}$ Pro, L-Phe, L-Leu, L-Val and L-Ser except for L-Ala and enzyme activity towards L-Pro was up to $4.06 \mathrm{U} \mathrm{mg}^{-1} \mathrm{~min}^{-1}$ in presence of $40 \%(\mathrm{v} / \mathrm{v})$ [MIM] [COO]. These results indicated that exposure to $[\mathrm{MIM}][\mathrm{COO}]$ changed the general enantioselectivity of DAAO toward many amino acids.

Table 1 The enzyme activity of DAAO with L-amino acids in presence of [MIM] [COO] $\left(37^{\circ} \mathrm{C}, \mathrm{pH} 9.0\right)$

Enzyme activity $\left(\mathrm{U} \mathrm{mg}^{-1} \mathrm{mim}^{-1}\right)$

\begin{tabular}{llll} 
Amino acids & $5 \%$ & $20 \%$ & $40 \%$ \\
\hline L-Ala & $0.82 \pm 0.09$ & $3.46 \pm 0.37$ & $4.26 \pm 0.09$ \\
L-Pro & $0.16 \pm 0.13$ & $0.31 \pm 0.02$ & $4.06 \pm 0.11$ \\
L-Met & NA $^{a}$ & $1.38 \pm 0.04$ & $3.65 \pm 0.44$ \\
L-Phe & NA & $1.61 \pm 0.06$ & $3.28 \pm 0.05$ \\
L-Leu & NA & $0.45 \pm 0.04$ & $2.27 \pm 0.57$ \\
L-Val & NA & $0.44 \pm 0.03$ & $2.17 \pm 0.07$ \\
L-Ser & NA & $0.41 \pm 0.03$ & $2.05 \pm 0.04$ \\
L-His & NA & $0.37 \pm 0.02$ & $1.83 \pm 0.11$ \\
L-Thr & NA & $0.36 \pm 0.33$ & $1.79 \pm 0.09$ \\
L-Tyr & NA & $0.29 \pm 0.05$ & $1.46 \pm 0.04$ \\
L-Gln & NA & $0.75 \pm 0.07$ & $1.26 \pm 0.09$ \\
L-Arg & NA & $0.24 \pm 0.04$ & $1.22 \pm 0.05$ \\
L-Trp & NA & $0.48 \pm 0.09$ & $0.92 \pm 0.08$ \\
L-Asn & NA & $0.18 \pm 0.01$ & $0.89 \pm 0.05$ \\
L-Cys & NA & $0.08 \pm 0.01$ & $0.39 \pm 0.03$
\end{tabular}

${ }^{a}$ NA: no activity. 
Confirmation of catalytic oxidation and analysis of conformational change in presence of ILs

In order to solidify the above idea, CE analysis was performed to detect whether L-amino acids were converted into their $\mathrm{D}^{-}$ isomers induced by [MIM][COO]. Compared with the signal of control, peak of D-Ala wasn't observed in the L-Ala solution containing $40 \%(\mathrm{v} / \mathrm{v})[\mathrm{MIM}][\mathrm{COO}]$ within the reaction time, which indicated that the L-Ala was not transformed to its mirrorimage configuration after [MIM][COO] treatment and [MIM] [COO] indeed mediated the oxidation of L-Ala catalyzed by DAAO during the reaction time. The similar results were obtained through the CE analysis of other L-amino acids (ESI Fig. S1 $\dagger$ ). As a consequence, it was concluded that the racemization of L-Ala did not occur during the reaction time in these experiments.

Subsequently, the structure of DAAO in the presence of ILs was further studied to make clear the reason responsible for alteration in enantioselectivity. The protein conformation of DAAO before and after [MIM] [COO] treatment was tested by CD spectrum analysis. Due to that a negative signal around $215 \mathrm{~nm}$ in CD spectrum was observed for DAAO in buffer, the conformation change of DAAO were monitored by the CD signal around $215 \mathrm{~nm}$ (taken as a reporter of the change in secondary structure). Changes in signal at $215 \mathrm{~nm}$ were shown in ESI Fig. S2. $\dagger$ Concerning the signal at $215 \mathrm{~nm}$, there were no remarkable changes in the $\mathrm{CD}$ spectrum of the DAAO in presence of $[\mathrm{BMIM}]\left[\mathrm{BF}_{4}\right],[\mathrm{BMIM}]\left[\mathrm{PF}_{6}\right]$ and $[\mathrm{MIM}][\mathrm{COO}]$ (ESI Fig. S2a and $\mathrm{b} \dagger$ and Fig. 5), suggesting that DAAO remained its native conformation. However, the CD spectrum of DAAO was moderately altered after [MPy $][\mathrm{COO}]$ treatment compared to that in buffer. A decrease was evident for the enzyme of CD signal in $215 \mathrm{~nm}$ (ESI Fig. S2c†), pointing to a decrease in secondary structure content. The analysis of CD spectrum of DAAO showed that the signal was almost disappeared after incubated with [BMIM]Cl, [EMIM]Br, [HMIM]Br, [OMIM] $\mathrm{Br}$, [BPy $][\mathrm{COO}], \quad[\mathrm{MIM}]\left[\mathrm{CH}_{3} \mathrm{CH}_{2} \mathrm{COO}\right]$ (ESI Fig. S2d-i†). The

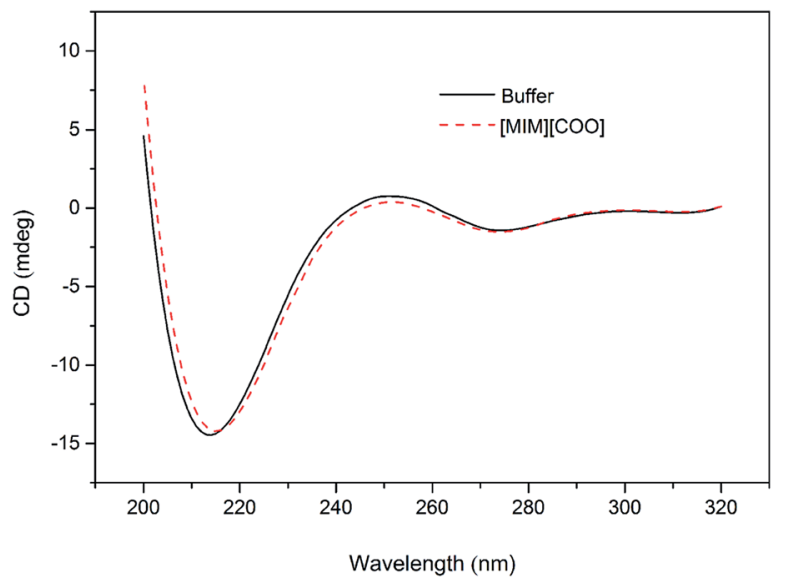

Fig. $5 \mathrm{CD}$ spectrum of DAAO in presence of ILs. The DAAO was preincubated with $40 \%(\mathrm{v} / \mathrm{v})$ ILs at $25^{\circ} \mathrm{C}$ for $15 \mathrm{~min}$ and the CD spectrum of DAAO were monitored by using $1.0 \mathrm{~cm}$ path length cuvette. The concentration of DAAO was $0.4 \mathrm{mg} \mathrm{mL}^{-1}$. structural change was accompanied by a sharp decrease of activity, which was consistent with previous reports that IL may lead to the secondary structure collapse in enzyme. ${ }^{30}$ But surprisingly, [MIM][COO] didn't result in conformational alteration of DAAO (Fig. 5), although [MIM][COO] induced enhancement of DAAO activities towards L-amino acids.

Due to that there is a change in the maximum emission of Trp and flavin with the change of solvent environment in proteins containing fluorophore residues, thus different microenvironment surroundings of the fluorophore residues of DAAO can be monitored by observing changes in the maximal intensity of fluorescence $\left(I_{\max }\right)$ and the red shift of the maximal emission wavelength $\left(\lambda_{\max }\right)$ of the Trp residues and flavin of the protein. ${ }^{31}$

To further explain the conformational change of DAAO in various ILs, fluorescence analysis for DAAO in the presence of ILs was carried out. The fluorescence spectra of DAAO after treatment with $40 \%(\mathrm{v} / \mathrm{v})$ ILs were illustrated in Fig. 6 and ESI Fig. S3. $\uparrow$ After incubation with $40 \%(\mathrm{v} / \mathrm{v})$ [BMIM] [BF 4 , [BMIM] $\left[\mathrm{PF}_{6}\right],[\mathrm{BMIM}] \mathrm{Cl},[\mathrm{MPy}][\mathrm{COO}]$ and $[\mathrm{MIM}][\mathrm{COO}]$ for $30 \mathrm{~min}$, the enzyme exhibited the same $\lambda_{\max }$ of Trp and flavin and the slightly decreases in $I_{\max }$ were observed, compared with that of in buffer. In contrast, with DAAO after $40 \%(\mathrm{v} / \mathrm{v})$ [OMIM]Br treatment, a noticeable red-shift (about $9 \mathrm{~nm}$ ) was observed in
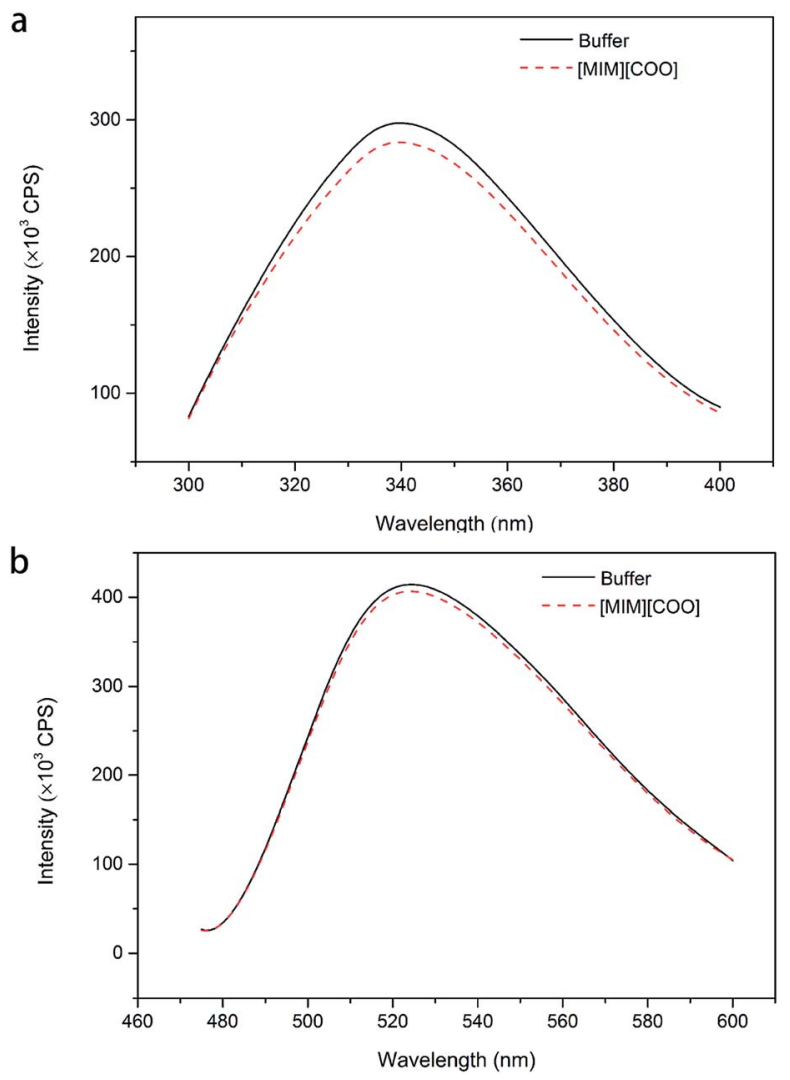

Fig. 6 Fluorescence spectra of DAAO in the presence of ILs. Fluorescence spectra of Trp (a) and flavin (b) of DAAO in borate saline buffer $(50 \mathrm{mM}, \mathrm{pH} 9.0)$ in the absence and presence of $40 \% \mathrm{IL}(\mathrm{v} / \mathrm{v})$ after incubation for $30 \mathrm{~min}$ at $25^{\circ} \mathrm{C}$. The excitation wavelength was 280 and $450 \mathrm{~nm}$, respectively. 
$\lambda_{\max }$ of Trp, accompanied by a significant increase in $I_{\max }$ of $\operatorname{Trp}$ (ESI Fig. S3a $\dagger$ ) and a sharp decrease in $I_{\max }$ flavin (ESI Fig. S3b $\dagger$ ). As for DAAO in presence of $40 \%$ (v/v) [EMIM]Br, [HMIM] Br, [BPy $] \mathrm{Br}$ and $[\mathrm{MIM}]\left[\mathrm{CH}_{3} \mathrm{CH}_{2} \mathrm{COO}\right]$, there were remarkable decreases in $I_{\max }$ of Trp and flavin as compared to that of control. Moreover, there were red-shifts (about $13 \mathrm{~nm}$ ) in $\lambda_{\max }$ of Trp for $[\mathrm{BPy}] \mathrm{Br}$ and $[\mathrm{MIM}]\left[\mathrm{CH}_{3} \mathrm{CH}_{2} \mathrm{COO}\right]$ treatment group. This suggested that [EMIM]Br, [HMIM]Br, [OMIM]Br, [BPy] Br and $[\mathrm{MIM}]\left[\mathrm{CH}_{3} \mathrm{CH}_{2} \mathrm{COO}\right]$ induced variation in protein structure, accompanied by an alteration of activity. It is evident that the addition of [MIM $][\mathrm{COO}]$ induces a tiny decrease in fluorescence intensity of DAAO, without any changes in the maximum emission wavelength and the shape of fluorescence spectra.

\section{Structural study of DAAO in ILs}

With the same anion, DAAO activity towards L-Ala in the existence of [MIM][COO] was sharply improved compared to that of [MPy][COO]. Previously, it's found that ILs comprising the $\mathrm{N}$ methylimidazolium group exhibits beneficial effects on activity than the one embracing the $N$-methylpyridinium group with the same anion..$^{32,33}$ The examination of DAAO activity in presence of imidazole and $N$-methylimidazole showed that there was no noticeable alteration in substrate specificity of DAAO (ESI Fig. $\mathrm{S} 4 \dagger)$. Therefore, it's inferred that $[\mathrm{MIM}]^{+}$plays a critical role in the alteration of enantioselectivity.

Data from CD and fluorescence showed no noticeable collapse of secondary structures and changes in the enzyme conformation induced by [MIM] [COO] (Fig. 5 and 6).

A close look at the active site structure of DAAO is necessary to understand the improved catalytic performance of DAAO modulated by [MIM] [COO]. The shape of the enzyme is a typical $\alpha / \beta$ fold (Fig. 7a). The key residues in binding site that are responsible for the catalytic activity of DAAO are Tyr 224, Tyr 228, Arg 283, Gly 313 and Gln 53 $3^{34,35}$ (Fig. 7b). The first step in oxidative deamination involves the nucleophilic attack of the hydroxyl group of Tyr 224 and Tyr 228 to the carbonyl carbon on the substrate to form an enzyme-substrate intermediate. The guanidine group of Arg 283 forms a salt bridge with $\alpha-\mathrm{COO}^{-}$of the substrate. The amino group of substrate is hydrogen bind with hydroxyl group of Tyr 224 and the backbone carbonyl of Gly 313 and Gln 53 which also form hydrogen bonds with bound water molecules. ${ }^{36}$ Moreover, D-Ala is tightly bound to the active site of the enzyme by noncovalent interaction, forming a quite stable transient intermediate. In contrast, the interactions of $\mathrm{L}^{-}$ Ala with the enzyme were shown in Fig. 7c. The coordination positions of $\alpha-\mathrm{COO}^{-}$are normally occupied by guanidine group from Arg 283, two hydroxyl group from the protein amino acid side chains of Tyr 224 and Tyr 228, and the amino group faces away from the carbonyl moiety of Gly 313 and Gln 53, thereby making the nucleophilic attack difficult (Fig. 7c).

Previous reports have shown that small structural changes in catalytic centre are important in biological and chemical processes. ${ }^{37,38}$ Water-miscible solvents can affect enzymatic performance by stripping off the essential water associated with the enzyme or penetrating into the micro-aqueous phase to interact with the enzyme by changing the protein dynamics,
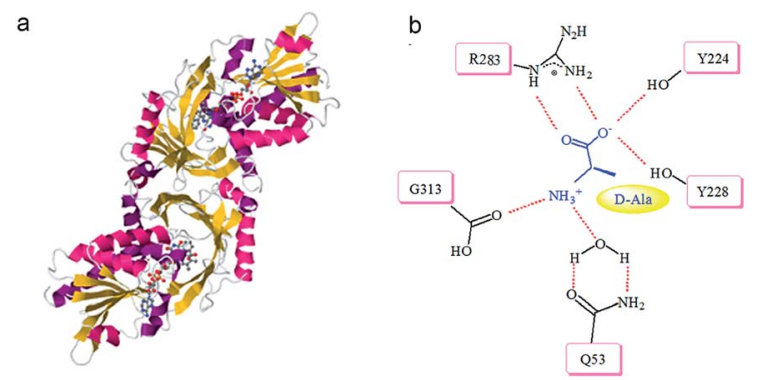

C
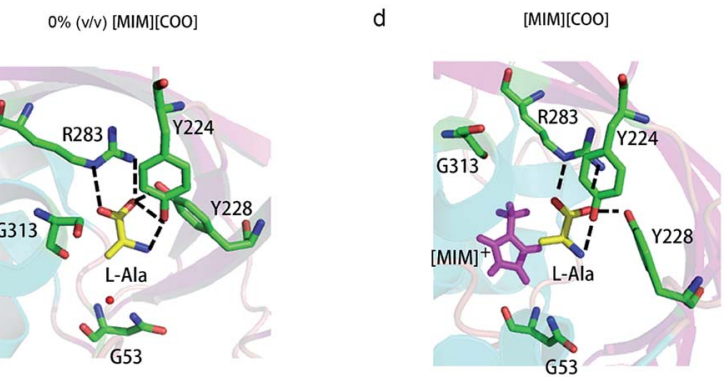

Fig. 7 Schematic drawing of interaction of DAAO-L-Ala complex with [MIM][COO]. (a) Detail of DAAO structure (PDB entry 1KIF). (b) Interactions between $\mathrm{D}$-Ala and DAAO. Schematic drawing of the active site cavity of DAAO in complex with L-Ala in absence (c) and presence (d) of [MIM][COO]. The active site residues were shown in stick representation coloured in green (carbon atoms), blue (nitrogen atoms) and red (oxygen atoms). The L-Ala molecule was shown in stick presentation, coloured in yellow (carbon atoms), blue (nitrogen atoms) and red (oxygen atoms). [MIM][COO] was shown in pink. $\mathrm{H}$-bonds were shown as dashed lines. Figure was prepared with PyMol.

conformation and/or the enzyme's active site. ${ }^{39}$ Since the reaction system has sufficient aqueous component, water stripping seems to be unlikely. Thus, a more direct interaction of the ILs with the enzyme may be responsible for the alteration in enantioselectivity.

We mimicked the binding mode of $[\mathrm{MIM}]^{+}$and D-amino acid oxidase with Surflex-Dock program in SYBYL8.0 software (Tripos Inc., St. Louis, MO, USA). The X-ray structure of D-amino acid oxidase download from Protein Data Base (http:// www.rcsb.org PDB code: 1C0P). The FAD was extracted from $1 \mathrm{C} 0 \mathrm{P}$ and used as reference, while the $[\mathrm{MIM}]^{+}$derived from FAD. Direct interaction of ILs with the catalytic site of the enzyme occurred due to structural adaptation between the active site of DAAO and the IL, as shown in Fig. 7c and $d$ and ESI Fig. S5. $\dagger$ The comparation of structure of the DAAO-L-Ala complex in buffer (Fig. 7c) and the DAAO-[MIM][COO]-L-Ala complex formed in presence of [MIM][COO] (Fig. 7d) showed that with existence of $[\mathrm{MIM}][\mathrm{COO}]$, L-Ala occupied the same region of the binding pocket as that of the L-Ala in buffer and the overall structure of DAAO-[MIM] [COO]-L-Ala is very similar to that previously reported in buffer. A large unoccupied patch of electron density in the entrance of the active site could be fitted with [MIM][COO]. It is reported that the reaction of Ala catalyzed by DAAO first dehydrogenates the amino acid to the corresponding imino acid, coupled with the reduction of FAD then hydrolyzes to the $\alpha$-keto acid and ammonia. ${ }^{40}$ Thus, the transfer of $\alpha$-proton to FAD and the attack of $\mathrm{H}_{2} \mathrm{O}$ to $\alpha$-amino group play key roles in 
catalyzed oxidization of amino acid. In buffer, L-Ala is tightly bound to the active site of the enzyme by noncovalent interaction, forming a quite stable transient intermediate, in which $\alpha$ $\mathrm{NH}_{3}$ group faces away from the carbonyl moiety. However, [MIM] cation can interact with surface residue (Tyr) through hydrophobic $\pi-\pi$ interactions due to a permanent positive charge and a $N$-methyl group of the imidazolium ring, which agrees with the previous report that most of the cations interact with hydrophobic regions on the surface of the enzyme. ${ }^{41}$ Thus, in presence of $[\mathrm{MIM}][\mathrm{COO}]$, the interaction between [MIM] cation and active site places L-Ala in a better attacking position to transfer of $\alpha$-proton to FAD or the nucleophilic attack to the amino group by water.

In comparison, $[\mathrm{MIM}]\left[\mathrm{CH}_{3} \mathrm{CH}_{2} \mathrm{COO}\right]$ has the same cation as [MIM][COO], whereas it doesn't enhance the activity of DAAO towards L-Ala. A possible reason is that larger steric structure and longer linear chain of $[\mathrm{MIM}]\left[\mathrm{CH}_{3} \mathrm{CH}_{2} \mathrm{COO}\right]$ blocks the entrance of $[\mathrm{MIM}]^{+}$to the active site area in the enzymatic reaction process. In contrast, with existence of [MIM] [COO], the electrostatic interaction of $[\mathrm{COO}]^{-}$and $[\mathrm{MIM}]^{+}$strengthens the interaction of $[\mathrm{MIM}]^{+}$with region of the binding pocket of DAAO. The data from kinetic studies with L-Ala as a substrate show a dramatic improvement in the affinity of the substrate (Fig. 4), indicates that a slight relaxation of active centre for the substrate induced by [MIM][COO]. In addition, $\mathrm{pH}$ had a synergistic effect on the alteration substrate specificity of DAAO based the optimization of $\mathrm{pH}$ (Fig. 3a). This was in consistent with our previous data that $\mathrm{pH}$ could mediate change in enantioselectivity of DAAO. ${ }^{25}$

\section{Conclusions}

In this study, the activities of DAAO towards L-Ala in presence of ten ILs were checked to evaluate the enantioselectivity of DAAO. It's observed that the activity of DAAO with L-Ala as substrate in presence of [MIM] [COO] was greatly enhanced and the enzyme activity of DAAO reached to a maximum of $4.26 \mathrm{U} \mathrm{mg}^{-1} \mathrm{~min}^{-1}$ in presence of $40 \%$ [MIM] [COO]. Furthermore, DAAO activities towards other L-amino acids such as L-Pro, L-Phe, L-Leu, L-Val and ${ }_{\mathrm{L}}$-Ser were also improved in [MIM] [COO]. CE, CD and fluorescence analysis confirmed the observations. [MIM] [COO] could induce alteration of the activities of DAAO towards $\mathrm{L}^{-}$ amino acids than the other 10 ILs such as [MIM] $\left[\mathrm{CH}_{3} \mathrm{CH}_{2} \mathrm{COO}\right]$. The alteration might also be related to a slight conformational relaxation of active centre for the DAAO due to [MIM] [COO] fitting into the binding pocket. Although the reason for the change of the activities of DAAO towards L-Ala need to be further explored, our investigation could offer a simple and effective method to predict the relaxation of the enantioselectivity of DAAO and thus guide the choice of a reaction system with the proper enantioselectivity.

\section{Conflict of interest}

The authors declare no competing financial interest.

\section{Author contribution statement}

Y. H. and X. L. conceived the idea and directed the work. Q. L. performed the experiments. C. Z. performed computational analysis. J. H. provided the ionic liquids. L. C. performed the CE analysis. K. Y., L. G., Y. D., \& C. Y. helped to analyse the results. Q. L. and L. W. analysed the experiments and wrote the main manuscript text. All authors reviewed the manuscript.

\section{Acknowledgements}

This work was sponsored by the National Natural Science Foundation of China (Grant No. 21272263), the State Key Laboratory of Natural and Biomimetic Drugs (No. K20140204), Universities of Chinese Academy of Sciences Grant (No. O8JT011J01), Fusion project of molecular science and education for Institute of Chemistry (Y52902HED2).

\section{Notes and references}

1 Z. Yang and W. B. Pan, Enzyme Microb. Technol., 2005, 37, 1928.

2 M. Moniruzzaman, N. Kamiya and M. Goto, Org. Biomol. Chem., 2010, 8, 2887-2899.

3 M. C. Bubalo, K. Hanousek, K. Radosevic, V. G. Srcek, T. Jakovljevic and I. R. Redovnikovic, Ecotoxicol. Environ. Saf., 2014, 101, 116-123.

4 M. Naushad, Z. A. ALOthman, A. B. Khan and M. Ali, Int. J. Biol. Macromol., 2012, 51, 555-560.

5 J. L. L. Carter, M. Bekhouche, A. Noiriel, L. J. Blum and B. Doumeche, ChemBioChem, 2014, 15, 2710-2718.

6 A. Chefson and K. Auclair, ChemBioChem, 2007, 8, 11891197.

7 D. Ajloo, M. Sangian, M. Ghadamgahi, M. Evini and A. A. Saboury, Int. J. Biol. Macromol., 2013, 55, 47-61.

8 M. F. Machado, R. P. Queiros, M. D. Santos, L. G. Fidalgo, I. Delgadillo and J. A. Saraiva, World J. Microbiol. Biotechnol., 2014, 30, 487-494.

9 H. S. Kim, D. Eom, Y. M. Koo and Y. G. Yingling, Phys. Chem. Chem. Phys., 2016, 18, 22062-22069.

10 H. Zhao and S. V. Malhotra, Biotechnol. Lett., 2002, 24, 12571260.

11 M. Goldfeder, M. Egozy, V. S. Ben-Yosef, N. Adir and A. Fishman, Appl. Microbiol. Biotechnol., 2013, 97, 19531961.

12 H. W. Yu, J. C. Wu and C. C. Bun, Chirality, 2005, 17, 16-21. 13 C. C. Barron, B. J. D. Sponagle, P. Arivalagan and G. B. D'Cunha, Enzyme Microb. Technol., 2017, 96, 151-156.

14 A. P. S. Brogans and J. P. Halleet, J. Am. Chem. Soc., 2016, 138, 4494-4501.

15 H. Zhao, J. Chem. Technol. Biotechnol., 2016, 91, 25-50.

16 P. F. Mugford, S. M. Lait, B. A. Keay and R. J. Kazlauskas, ChemBioChem, 2004, 5, 980-987.

17 A. Mattevi, G. Tedeschi, L. Bacchella, A. Coda, A. Negri and S. Ronchi, Struct. Anal., Folding Des., 1999, 7, 745-756.

18 G. M. Brearley, C. P. Price, T. Atkinson and P. M. Hammond, Appl. Microbiol. Biotechnol., 1994, 41, 670-676. 
19 K. Yagi and M. Nishikimi, J. Biochem., 1968, 64, 371-376.

20 X. Jin, B. K. Liu, Z. Ni, Q. Wu and X. F. Lin, Enzyme Microb. Technol., 2011, 48, 454-457.

21 S. Emond, D. Guieysse, S. Lechevallier, J. Dexpert-Ghys, P. Monsan and M. Remaud-Simeon, Chem. Commun., 2012, 48, 1314-1316.

22 M. Ivancic, G. Valinger, K. Gruber and H. Schwab, J. Biotechnol., 2007, 129, 109-122.

23 Y. Ijima, K. Matoishi, Y. Terao, N. Doi, H. Yanagawa and H. Ohta, Chem. Commun., 2005, 877-879.

24 S. Bartsch, R. Kourist and U. T. Bornscheuer, Angew. Chem., Int. Ed., 2008, 47, 1508-1511.

25 Q. Liu, L. Chen, Z. Zhang, B. Du, Y. Xiao, K. Yang, L. Gong, L. Wu, X. Li and Y. He, Sci. Rep., 2017, 7, 2994.

26 S. Lutz-Wahl, E. M. Trost, B. Wagner, A. Manns and L. Fischer, J. Biotechnol., 2006, 124, 163-171.

27 Y. Nishiya and T. Imanaka, FEBS Lett., 1998, 438, 263-266.

28 A. Kurata, H. Senoo, Y. Ikeda, H. Kaida, C. Matsuhara and N. Kishimoto, Extremophiles, 2016, 20, 415-424.

29 A. I. Akhmetshina, O. R. Gumerova, A. A. Atlaskin, A. N. Petukhov, T. S. Sazanova, N. R. Yanbikov, A. V. Nyuchev, E. N. Razov and I. V. Vorotyntsev, Sep. Purif. Technol., 2017, 176, 92-106.

30 S. Ghaedizadeh, R. Emamzadeh, M. Nazari, S. M. M. Rasa, S. H. Zarkesh-Esfahani and M. Yousefi, Biochem. Eng. J., 2016, 105, 505-513.
31 L. Caldinelli, S. Iametti, A. Barbiroli, F. Bonomi, L. Piubelli, P. Ferranti, G. Picariello, M. S. Pilone and L. Pollegioni, J. Biol. Chem., 2004, 279, 28426-28434.

32 J. L. Kaar, A. M. Jesionowski, J. A. Berberich, R. Moulton and A. J. Russell, J. Am. Chem. Soc., 2003, 125, 4125-4131.

33 L. Suresh, P. Onkara, P. S. V. Kumar, Y. Pydisetty and G. V. P. Chandramouli, Bioorg. Med. Chem. Lett., 2016, 26, 4007-4014.

34 M. Bakke and N. Kajiyama, Appl. Biochem. Biotechnol., 2004, 112, 123-131.

35 A. Nueangaudom, K. Lugsanangarm, S. Pianwanit, S. Kokpol, N. Nunthaboot and F. Tanaka, Phys. Chem. Chem. Phys., 2012, 14, 2567-2578.

36 M. G. Sarower, S. Okada and H. Abe, ScienceAsia, 2009, 35, 150-155.

37 A. D. Mesecar, B. L. Stoddard and D. E. Koshland, Science, 1997, 277, 202-206.

38 D. E. Koshland, Nat. Med., 1998, 4, 1112-1114.

39 A. Zaks and A. M. Klibanov, J. Biol. Chem., 1988, 263, 80178021.

40 M. S. Pilone, Cell. Mol. Life Sci., 2000, 57, 1732-1747.

41 E. M. Nordwald, J. G. Plaks, J. R. Snell, M. C. Sousa and J. L. Kaar, ChemBioChem, 2015, 16, 2456-2459. 